\title{
TOTOBUANG
}

Volume $7 \quad$ Nomor 1, Juni 2019

Halaman 57-71

\section{MODUS TINDAK TUTUR EKPRESIF DALAM TRANSAKSI JUAL-BELI DI PASAR TRADISIONAL KOTA BAUBAU: TINJAUAN PRAGMATIK (Modus Speech Act in The Interaction of Selling-Buying in Traditional Market of Baubau City: A Pragmatic Study)}

\author{
Harziko \\ Universitas Iqra Buru \\ JI. Prof. Dr. A. Bassalamah, No. 20, Namlea, Buru \\ Pos-el: harziko91@gmail.com \\ (Dikirim: 18 Maret 2019; Direvisi:7 Mei 2019; Diterima: 4 Juni 2019)
}

\begin{abstract}
This research aims to describe the uses of speech modus of the vendor and buyers. The research was descriptive and qualitative. The samples were chosen using the purposive sampling technique. The linguistic phenomena was analyzed using the pragmatic approach. The data camprised the oral data obtained from the conversation between the vendors and the buyers in the selling-buying interaction. The data were collected using the method of observation through the techniques of recording and noting. The classified data were then analyzed descriptively and qualitatively. The results showed that (1) the use of the seller speech mode consists of modes declarative, interrogative mode, and the imperative mood. Interrogative mode is used to ask the seller as well invite shoppers to browse and select items they need. Seller declarative mode is used to maintain prices (reject) the buyer's bid by way of mentioning the source and price of goods. Seller imperative mood used to persuade buyers to try every item offered by a seller. Furthermore, the use of speech mode consists of modes buyer declarative, interrogative mode, and the imperative mood. Declarative mode is used buyers in an attempt to bargain the price of goods in a way to convey that he is a subscription often buy goods sold sellers. Modus interrogative used buyers to ask at once aimed at bargain prices, while the imperative mood used buyers who aimed ask the seller to reduce the price of goods according to buyer demand.
\end{abstract}

Keywords: mode, vendors and buyers, conversation.

\begin{abstract}
Abstrak
Penelitian ini bertujuan mendeskripsikan modus tindak tutur penjual dan pembeli di pasar tradisional Kota Baubau. Penelitian ini bersifat deskriptif kualitatif. Pengambilan sampel dilakukan secara purposive sampling. Fenomena kebahasaan dikaji dengan pendekatan pragmatik. Data penelitian berupa data lisan yang bersumber dari percakapan penjual dan pembeli dalam transaksi jual-beli. Data dikumpulkan dengan menggunakan metode simak melalui teknik rekam dan catat. Data yang telah diklasifikasi, dianalisis secara deskriptif kualitatif. Hasil penelitian menunjukkan bahwa penggunaan modus tuturan penjual terdiri atas modus deklaratif, modus interogatif, dan modus imperatif. Modus interogatif penjual digunakan untuk menanyakan sekaligus mempersilakan pembeli untuk mencari dan memilih barang yang dibutuhkannya. Modus deklaratif penjual digunakan untuk mempertahankan harga (menolak) tawaran pembeli dengan cara menyebutkan sumber dan harga barang. Modus imperatif penjual digunakan untuk membujuk pembeli agar mencoba tiap-tiap barang yang ditawarkan oleh penjual. Selanjutnya, penggunaan modus tuturan pembeli terdiri atas modus deklaratif, modus interogatif, dan modus imperatif. Modus deklaratif digunakan pembeli sebagai upaya menawar harga barang dengan cara menyampaikan bahwa dirinya merupakan langganan yang sering membeli barang yang dijajakan penjual. Modus interogatif digunakan pembeli untuk bertanya sekaligus bertujuan menawar harga, sedangkan modus imperatif digunakan pembeli yang bertujuan meminta penjual agar mengurangi harga barang sesuai permintaan pembeli.
\end{abstract}

Kata-kata kunci: modus, penjual dan pembeli, percakapan. 



\section{PENDAHULUAN}

Tindak tutur ekspresif tidak lepas dari penggunaan bahasa mengingat bahasa begitu penting dalam menunjang aktivitas sehari-hari. Sejalan dengan itu, Taufik (2017:325) menyatakan bahwa ketika seorang pembicara menggunakan bahasa yang tidak dipahami dalam komunikasi maka pesan yang disampaian oleh pembicara tidak akan sampai kepada pendengar. Hal itu terjadi pula dalam transaksi antara penjual dan pembeli yang lebih dominan terjadi di pasar.

Interaksi penjual dan pembeli dibangun melalui percakapan dalam proses tawar-menawar. Dalam interaksi sosial yang dibangun melalui tawar-menawar, pembeli diposisikan layaknya raja dan penjual menempatkan dirinya sebagai pelayan untuk meningkatkan pelayanan yang memuaskan pembeli. Hal tersebut akan tercapai apabila penjual mempunyai keterampilan menawarkan barang yang dijual. Selain itu, penjual harus pula menyesuaikan tuturannya dengan kebutuhan pembeli. Demikian halnya dengan pembeli, salah satu keterampilan pembeli adalah menawar harga barang yang dipilihnya. Pada proses tersebut, penjual dan pembeli akan menghasilkan keberagaman tuturan dengan harapan setiap maksud tuturannya dapat dipahami.

Penjual dan pembeli membangun percakapan sebagai salah satu titik dari rangkaian alur proses jual-beli untuk mewujudkan keinginannya. Tentu hal ini akan meningkatkan prespektif bahwa penjual dan pembeli masing-masing memiliki power pada interaksi jual-beli. Dengan demikian, penjual menggunakan tuturan untuk menjelaskan segala sesuatu yang ingin diungkapkannya berkaitan dengan produk atau barang yang dijual. Hal tersebut berlaku sebaliknya kepada pembeli. Pembeli akan mengungkapkan keinginannya untuk memperoleh barang atau produk yang dibutuhkan.

Dalam ranah pasar, interaksi jual-beli tidak lepas dari bahasa sebagai produk perantara penjual dan pembeli. Pasar tradisional bukan sekadar pranata ekonomi, melainkan menyangkut sosial budaya karena masyarakat pasar adalah masyarakat yang multikultur dan multibahasa. Taufik (2018:156) menyatakan bahwa hampir setiap daerah yang ada di Indonesia memiliki bahasa daerah dan dialeknya sendiri. Oleh karena itu, pemilihan bahasa yang sesuai dalam tindak tutur sangat penting.

Tarigan (1990:36) menyatakan bahwa berkaitan dengan tindak tutur maka setiap ujaran atau ucapan tertentu akan mengandung maksud dan tujuan tertentu pula. Dengan kata lain, penutur dan mitra tutur yang terlibat dalam peristiwa tutur akan menghasilkan tuturan yang berorientasi pada maksud tertentu. Pada peristiwa tutur, penjual dan pembeli dapat berinteraksi melalui proses tawar-menawar.

Dalam proses tawar-menawar akan berlangsung dengan baik apabila terjadinya kebersamaan dan kesepahaman pada maksud tuturan yang diujarkan. Dengan demikian, tuturan yang disampaikan penjual dapat dimengerti maksudnya oleh pembeli. Begitu pun sebaliknya, tuturan yang disampaikan pembeli dapat dipahami maksudnya oleh penjual. Meskipun demikian, kesepahaman dalam proses tawar-menawar dapat memunculkan keanekaragaman tuturan yang dapat menyebabkan makna tuturan menjadi berbeda. Hal tersebut dipengaruhi oleh berkembangnya setiap tuturan dalam percakapan penjual dan pembeli. Berkembangnya setiap tuturan dalam percakapan, dibutuhkan konstribusi konteks untuk mengungkap maksud tuturan dalam percakapan.

Merayu pembeli, menawarkan produk, dan menawarkan harga, tidak terlepas dari usaha penjual menjajakan barang dagangannya agar laku terjual. Penggunaan bahasa menjadi hal yang penting untuk tercapainya ketiga hal tersebut. Selain membutuhkan kemampuan penjual dalam menggunakan bahasa, ketepatan dan kejujuran mengujarkan tuturan menjadi hal yang penting dalam rangka menciptakan komunikasi yang nyaman antara penjual dan pembeli. Hal 
tersebut berlaku di pasar tradisional. Berbeda halnya dengan pasar modern. Penjual dan pembeli di pasar modern tidak melakukan proses tawar-menawar dikarenakan harga barang yang tentatif (belum tetap/pasti). Artinya, barang yang dijajakan di pasar modern sudah ditentukan harganya melalui label yang ditempel pada masing-masing barang.

Kenyataannya, di pasar tradisonal terjadi transaksi jual-beli yang disertai dengan proses tawar-menawar. Penjual akan menawarkan produk kepada pembeli. Hal tersebut berlaku sebaliknya pada pembeli. Pembeli akan menawar barang yang dipilihnya sesuai dengan keinginannya. Apabila penjual dan pembeli memiliki kesepakatan harga, maka proses transaksi keduanya akan berlangsung dengan baik. Di sisi lain, keberlangsungan tawar-menawar dapat menimbulkan ketidakcocokan harga barang antara penjual dan pembeli. Hal ini dilandasi oleh latar belakang pengetahuan penjual dan pembeli terhadap harga barang. Dengan demikian, baik penjual dan pembeli akan memainkan perannya dalam mengekspresikan tuturannya untuk memenuhi keinginannya. Tentu hal tersebut dapat pula mempengaruhi maksud ujaran yang diproduksi berdasarkan pengertian dan acuan tuturannya. Di sisi lain, penjual dan pembeli akan memproduksi tuturan tertentu untuk menghasilkan efek lain dari tuturannya.

Tentunya dalam berkomunikasi, baik penjual maupun pembeli memiliki kepentingan agar maksud yang diungkapkan dapat berterima dan sesuai dengan harapan mereka. Fenomena yang terjadi, penolakan atau kritikan penjual dan pembeli dituturkan secara langsung dan apa adanya berdasarkan pengalamannya sehingga terkadang dapat mengakibatkan kesalahpahaman oleh keduanya. Menurut Brown dan Levinson (dalam Gunawan 2013:9) menjaga keterancaman muka atau menjaga harga diri ini penting dilakukan baik penutur maupun mitra tuturnya. Hal ini bertujuan untuk menghindari saling ketersinggungan yang diakibatkan oleh tutur kata dan berujung pada kesalahpahaman. Berdasarkan hal tersebut, semestinya penjual dan pembeli saling memahami maksud setiap tuturan yang tidak sesuai pada pengertian atau acuan dalam percakapan. Sehubungan dengan hal tersebut, setiap tuturan penjual dan pembeli direpresentasikan dengan modus kalimat yang mengandung maksud yang tidak senyatanya pada acuan dalam percakapan. Berikut ini, peneliti akan menguraikan tuturan penjual dan pembeli yang mengandung modus kalimat.

\section{Contoh (1)}

Konteks : Seorang pembeli sedang menawar harga baju kepada penjual pakaian.

Tempat : Di pasar Laelangi Kota Baubau

Peserta : Penjual dan pembeli

\section{Percakapan:}

Pembeli : Berapa harga baju yang ini, Bu?

Penjual : Lima puluh ribu.

Pembeli : Dua puluh lima ribu mo.

Penjual : Modalnya saja tidak sampai, belum lagi ongkos perjalanannya.

Pembeli : Oh iya makasih, Bu. (pergi).

Modus deklaratif penjual pada contoh (1) terdapat pada kalimat modalnya saja tidak sampai, belum lagi ongkos perjalanannya. Kalimat tersebut merupakan kalimat majemuk bertingkat yang terdiri atas kalimat utama modalnya saja tidak sampai dan anak kalimat belum lagi ongkos perjalanannya. Kalimat utama bermakna modal barang lebih besar dari nominal harga yang diajukan pembeli. Adapun anak kalimat merupakan penegasan terhadap kalimat utama tentang harga yang diajukan oleh pembeli tidak mencapai modal dasar barang tersebut. Dengan demikian, dapat dipahami bahwa penjual berupaya merasionalkan harga baju sehingga pembeli bisa memahami keadaan sebenarnya tentang modal baju dan keuntungan yang mesti diperoleh penjual.

Merujuk pada percakapan contoh (1), maka tampak bahwa interaksi jual-beli tidak mencapai kesepakatan harga dengan kata 
lain tidak berhasil. Hal ini ditandai pada kalimat oh ia makasih, Bu (pergi) yang dituturkan oleh pembeli. Ketidakberhasilan transaksi tersebut disebabkan oleh dua hal: pertama, baju bukan merupakan kebutuhan mendesak (sekunder); kedua, penjual baju di pasar tersebut banyak sehingga pembeli merasa masih bisa mendapatkan barang serupa di tempat lain sesuai harga yang diinginkan.

Berdasarkan fenomena di atas peneliti tertarik untuk meneliti percakapan penjual dan pembeli yang dilatarbelakangi oleh beberapa hal, antara lain: a) beragamnya penggunaan modus tuturan yang kadang-kadang tidak sesuai dengan fungsi sebenarnya, b) percakapan penjual dan pembeli hanya sekadar dipandang sebagai salah satu titik dari rangkaian alur proses percakapan untuk memenuhi keinginannya, c) setiap penjual dan pembeli memiliki gaya, cara, dan teknik masingmasing pada momen tawar-menawar untuk memperoleh atau memenuhi keinginannya. Penelitian ini merupakan salah satu penelitian dengan dasar tinjauan pragmatik. Tinjauan pragmatik digunakan untuk mengungkap berbagai macam bentuk tuturan, makna, maksud, dan aspek-aspek situasi tutur dalam percakapan. Hal ini sejalan dengan pendapat Kridalaksana (1993:177) menyatakan bahwa pragmatik (pragmatics) adalah ilmu yang menyelidiki pertuturan, konteksnya, dan maknanya. Selain itu, Zamzani (2007:18-23) berpendapat kajian pragmatik selalu terarah pada permasalahan bahasa dalam suatu masyarakat.

Berdasarkan fenomena tuturan ekspresif penjual dan pembeli yang selalu direpresentasikan dengan modus kalimat yang mengandung maksud yang tidak senyatanya pada acuan dalam percakapan, maka yang menjadi fokus dalam penelitian ini, mendeskripsikan modus tindak tutur penjual dan pembeli di pasar tradisional Kota Baubau.

\section{LANDASAN TEORI}

\section{Teori Pragmatik}

Pragmatik

pertama-tama

diperkenalkan oleh seorang filsuf pada tahun 1938 yang bernama Charles Morris. Dia membagi ilmu tentang tanda atau semiotik menjadi tiga konsep dasar, yaitu sintaksis, semantik, dan pragmatik.

Pragmatik merujuk pada kajian makna dalam interaksi antara seorang penutur dengan mitra tutur. Thomas (1995:22) mendefenisikan pragmatik sebagai bidang ilmu yang mengkaji makna dalam interaksi atau "meaning in interpretation". Pengertian tersebut dengan mengandaikan bahwa pemaknaan merupakan proses dinamis yang melibatkan negosiasi antara pembicara dan pendengar serta konteks ujaran (fisik, sosial, dan linguistik) serta makna potensial yang mungkin dari sebuah ujaran. Soeparno (2002:27) pragmatik adalah subdisiplin linguistik yang mempelajari penerapan atau penggunaan bahasa dalam komunikasi sosial harus memperhatikan faktor-faktor situasi, maksud pembicaraan, dan status lawan tutur. Selanjutnya, Leech (1993:9) pragmatik adalah studi tentang makna dalam hubungannya dengan situasi ujar (speech situations). Pragmatik diperlukan dengan menganalisis makna yang dipertuturkan antara penutur disesuaikan dengan situasi ujar.

Yule (2006:3) menyebutkan empat definisi pragmatik, yaitu:

a) Pragmatik adalah bidang yang mengkaji makna pembicara.

b) Pragmatik adalah bidang yang mengkaji makna menurut konteksnya.

c) Pragmatik adalah bidang yang melebihi kajian tentang makna yang diujarkan, mengkaji makna yang dikomunikasikan atau terkomunikasikan oleh pembicara.

d) Pragmatik adalah bidang yang mengkaji bentuk ekspresi menurut jarak sosial yang membatasi partisipan yang terlibat dalam percakapan tertentu.

Menurut Gusnawaty (2011:16-17) pragmatik berfokus utama pada dua kata kunci, yakni penggunaan bahasa dalam 
konteksnya, dan makna yang ditimbulkan akibat interaksi sosial yang bergantung pada hubungan solidaritas atau jarak antara interlokutor. Pertama, yakni penggunaan bahasa dalam konteksnya. Pernyataan ini sangat penting karena sebuah tuturan yang sama dapat memiliki arti yang berbeda jika berada pada konteks yang berbeda. Misalnya, teks harga di pasar tradisional dan di pasar modern memiliki makna yang berbeda. Harga di pasar tradisional masih dapat ditawar sedangkan di pasar modern sudah tetap.

\section{Pengertian Tindak Tutur}

Tindak tutur dalam pragmatik merupakan salah satu konsep dalam kebahasaan. Menurut Rustono (1999:31) tindak tutur (speech act) merupakan entitas yang bersifat sentral dalam pragmatik. Oleh karena sifatnya yang sentral itulah, tindak tutur bersifat pokok di dalam pragmatik. Mengujarkan sebuah tuturan tertentu bisa dipandang sebagai melakukan tindakan (mempengaruhi, menyuruh) di samping memang mengucapkan atau mengujarkan tuturan itu. Chaer (dalam Rohmadi, 2004:29) tindak tutur merupakan gejala individual yang bersifat psikologis dan keberlangsungan ditentukan oleh kemampuan bahasa penutur dalam menghadapi situasi tertentu.

Tindak tutur merupakan gejala individual, bersifat psikologis dan keberlangsungannya ditentukan oleh kemampuan bahasa si penutur dalam menghadapi situasi tertentu. Dalam tindak tutur lebih dilihat pada makna atau arti tindakan dalam tuturannya (Chaer dan Agustina, 2004:50). Tindak tutur dapat dikatakan sebagai penggunaan atau pemakaian sepenggal bahasa, dapat berupa kalimat, frase, dan kata yang diungkapkan oleh seseorang pada suatu kesempatan atau peristiwa tertentu. Selanjutnya menurut Richard (dalam Syamsuddin, 1992:46) berpendapat bahwa tindak tutur adalah sesuatu yang kita lakukan dalam rangka berbicara atau suatu unit bahasa yang berfungsi di dalam sebuah percakapan.
Berdasarkan pendapat para pakar di atas, dapat disimpulkan bahwa tindak tutur adalah suatu ujaran disampaikan melalui bahasa yang didasarkan pada hubungan tuturan dengan tindakan yang dilakukan oleh penutur kepada mitra tuturnya dalam berkomunikasi.

\section{Situasi Tutur}

Maksud ujaran penutur dan mitra tutur dapat diidentifikasi berdasarkan situasi tutur. Dalam perilaku tertentu, penutur dan mitra tutur akan menunjukkan kenyataan ujaran-ujarannya sesuai situasi tutur yang mendukungnya. Demikian pula, penjual dan pembeli dapat mengekspresikan tindakan atau ujarannya sesuai dengan situasi tutur yang mendukungnya. Berkaitan dengan hal tersebut, berikut ini akan diuraikan konsep situasi tutur.

Sebagai salah satu cabang ilmu bahasa yang berkaitan langsung dengan peristiwa komunikasi, maka pragmatik tidak dapat dipisahkan dari konsep situasi tutur. Dengan menggunakan analisis pragmatis, maksud atau tujuan dari sebuah peristiwa tutur dapat diidentifikasikan dengan mengamati situasi tutur yang menyertainya. Rustono (1999:26) menyatakan bahwa situasi tutur adalah situasi yang melahirkan tuturan. Maksud tuturan yang sebenarnya hanya dapat diidentifikasi melalui situasi tutur yang mendukungnya. Selanjutnya Effendy (2004:11), mengatakan bahwa proses komunikasi berlangsung dalam konteks situasional, komunikator harus memperhatikan situasi ketika komunikasi dilangsungkan, sebab situasi sangat berpengaruh terhadap kelancaran komunikasi, terutama situasi yang berhubungan dengan faktor-faktor sosiologis, antropologis, dan psikologis.

Sebuah peristiwa tutur dapat terjadi karena adanya situasi yang mendorong terjadinya peristiwa tutur tersebut. Situasi tutur sangat penting dalam kajian pragmatik, karena dengan adanya situasi tutur, maksud dari sebuah tuturan dapat diidentifikasikan dan dipahami oleh mitra tuturnya. Penjelasan mengenai situasi dikemukakan 
oleh Leech (1993:19-20) yang membagi aspek-aspek situasi tutur menjadi lima macam yaitu: (a) penutur dan mitra tutur, (b) konteks tuturan, (c) tujuan sebuah tuturan, (d) tuturan sebagai bentuk kegiatan atau tindakan, (e) tuturan sebagai produk tindak verbal.

Pragmatik berhubungan dengan produk tindak verbal (verbal act) yang terjadi dalam situasi tertentu. Tuturan tercipta melalui tindakan verbal, maka tuturan itu merupakan hasil tindak verbal. Tindakan verbal adalah tindakan yang mengekspresikan kata-kata atau bahasa.

Situasi tutur dalam kajian pragmatik memiliki peran yang sangat penting, yakni sebagai bahan pertimbangan untuk mengungkapkan suatu maksud tutur yang terdapat dalam peristiwa tutur. Menurut Hymes (dalam Pranowo, 2009:101) mengemukakan beberapa komponen tutur yang diakronimkan dengan istilah SPEAKING yang perlu diperhatikan seseorang dalam berkomunikasi, yaitu sebagai berikut.

1. Setting and scene (latar) mengacu pada tempat dan terjadinya komunikasi.

2. Participants (peserta) mengacu pada orang yang terlibat dalam komunikasi (penutur dan mitra tutur).

3. Ends (tujuan komunikasi) mengacu pada tujuan yang ingin dicapai dalam berkomunikasi.

4. Act sequence (pesan yang ingin disampaikan) mengacu pada bentuk dan pesan yang ingin disampaikan.

5. Key (kunci) mengacu pada pelaksanaan percakapan. Maksudnya, bagaimana pesan itu disampaikan kepada petutur.

6. Norms (norma), yaitu pranata sosial kemasyarakatan yang mengacu pada norma perilaku dalam percakapan.

7. Genres (ragam, register) mengacu pada ragam bahasa yang digunakan, misalnya ragam formal dan nonformal.

\section{Klasifikasi Tindak Tutur}

Menurut Austin (1962:94-107) membagi tindak tutur menjadi tiga macam tindakan yaitu, tindakan menginformasikan atau menyatakan sesuatu "The act of saying something", yaitu dengan tindak lokusi, tindakan menghendaki mitra tuturnya untuk melakukan sesuatu "The act of doing something" yang disebut dengan tindak ilokusi, dan tindakan memberikan pengaruh kapada mitra tutur atau menghendaki adanya reaksi atau efek atau hasil tertentu dari mitra tutur "The act of affecting someone" yang disebut dengan tindak perlokusi. Berikut pembahasan ketiganya.

\section{Tindak Lokusi}

Tindak tutur lokusi adalah tindak tutur yang menyatakan sesuatu dalam arti berkata atau tindak tutur dalam bentuk kalimat yang bermakna dan dapat dipahami (Chaer dan Agustina, 2004:53). Menurut Rahardi (2008:35) tindak tutur lokusi adalah tindak bertutur dengan kata, frasa dan kalimat itu. Sendilatta (2008:8) mengatakan tindak tutur lokusi adalah tindak bertutur dengan kata, frasa, dan kalimat sesuai dengan makna yang dikandung oleh kata, frasa, dan kalimat tersebut. Selanjutnya menurut Yule (2006:83) tindak lokusi merupakan tindak dasar tuturan atau menghasilkan suatu ungkapan linguistik yang bermakna. Berdasarkan pendapat di atas dapat disimpulkan bahwa pada dasarnya dalam bentuk lokusi ini tidak dipermasalahkan lagi fungsi tuturannya karena makna yang dimaksudkan adalah memang benar makna yang terdapat pada kalimat diujarkan.

\section{Tindak Ilokusi}

Tuturan ilokusi selain berfungsi untuk menyampaikan atau menginformasikan sesuatu, juga dapat melakukan sesuatu. Tindak tutur ilokusi merupakan tindak tutur yang mengandung makna tersembunyi atau makna lain yang dikehendaki oleh penutur terhadap mitra tutur. Menurut Ibrahim (1993:115) tindak ilokusi dilakukan dengan mengatakan sesuatu yang mencakup tindakan-tindakan seperti bertaruh, berjanji, menolak, dan memesan. 


\section{Tindak Tutur Perlokusi}

Menurut Wijana (1996:20) tindak

tutur perlokusi merupakan sebuah

yang diutarakan oleh seseorang ser

mempunyai daya pengaruh (perlocuiıvrury force), atau efek bagi yang mendengarkannya. Rohmadi (2004:31) yang menyatakan bahwa tindak tutur perlokusi adalah tindak tutur yang pengutaraannya dimaksudkan untuk mempengaruhi lawan tuturnya. Dengan demikian dapat disimpulkan bahwa tindak tutur perlokusi adalah tindak tutur yang memiliki makna untuk mempengaruhi pendengarnya atau dimaksudkan untuk mempengaruhi mitra tutur.

\section{Modus}

Modus adalah pengungkapan atau penggambaran suasana psikologis perbuatan menurut tafsiran atau sikap si pembicara tentang apa yang diucapkannya. Sehubungan dengan hal tersebut, Djajasudarma (1999:34) berpendapat bahwa modus adalah istilah linguistik yang menyatakan makna verba mengungkapkan suasana kejiwaan sehubungan dengan perbuatan menurut tafsiran pembicara atau sikap pembicaraan tentang yang diucapkannya.

Berdasarkan modusnya, Wijana (1996:30) membedakan tuturan menjadi tiga, yaitu tuturan bermodus deklaratif, modus interogatif, dan modus imperatif.

\section{Modus berita (deklaratif)}

Modus berita (deklaratif) digunakan untuk memberitakan sesuatu (informasi). Hal tersebut sejalan dengan pendapat Cook (1971:38) kalimat deklaratif adalah kalimat yang dibentuk untuk menyiarkan informasi tanpa mengharapkan respons tertentu. Selanjutnya Ramlan (2005:27) kalimat berita adalah kalimat yang fungsinya untuk memberitahukan sesuatu kepada orang lain hingga tanggapan yang diharapkan hanyalah berupa perhatian seperti tercermin pada pandangan mata yang menunjukan adanya perhatian.
2. Modus Interogatif

Modus interogatif digunakan untuk yakan sesuatu. Secara konvesional interogatif ditandai dengan tanda tanya (?).

\section{Modus Imperatif}

Modus imperatif merupakan modus kalimat yang dibentuk memancing respon yang berupa tindakan (Cook, 1971:38). Selanjutnya Ramlan (2005:39) mengemukakan bahwa berdasarkan fungsinya dalam hubungan situasi, kalimat perintah mengharapkan tanggapan yang berupa tindakan dari orang yang diajak berbicara. Berikut ini akan disajikan contoh kalimat imperatif.

\section{Tindak tutur Ekspresif}

Tindak tutur ekspresif

mengimplikasikan bahwa penutur mempunyai fungsi untuk mengekspresikan, mengungkapkan atau memberitahukan sikap sikologis sang pembicara menuju suatu pernyataan keadaan yang diperkirakan oleh ilokusi. Misalnya mengucapkan terima kasih, mengucapkan selamat, memuji, humor, mengajak, menolak, basa-basi dan sebagainya. Menurut Searle (dalam Rani, dkk, 2006:239) tindak ekspresif berfungsi untuk mengekspresikan sikap psikologis pembicara terhadap pendengar sehubungan dengan keadaan tertentu. Misalnya, penggunaan realisasi wujud tindak tutur ekspresif 'menolak' yang dicontohkan oleh Noer (2016:165).

"Pokoknya saya selama ada transaksi uang dengan barang 'no' jangan"

Tuturan di atas merupakan tindak tutur ekspresif 'menolak'. Penutur menggunakan penanda lingual 'no' yang berarti 'tidak' dan 'jangan' yang menunjukan ketidaksepakatan mengenai tawaran dari salah satu sponsor sehingga penutur menolak kerja sama dengan sponsor terkait.

\section{METODE}

Penelitian ini merupakan jenis penelitian deskriptif kualitatif dengan 
menggunakan pendekatan pragmatik. Penelitian deskriptif kualitatif adalah penelitian yang mengidentifikasi, mengklasifikasi, menganalisis data yang telah diperoleh, dan mendeskripsikannya melalui penggambaran bahasa sebagaimana adanya. Dengan demikian, pendeskripsian data dalam penelitian ini berupa tuturan penjual dan pembeli di pasar tradisional Kota Baubau dari segi modus dan fungsi tindak tutur ekspresif dalam transaksi jualbeli mereka dengan menggunakan konsepkonsep teori yang telah dikembangkan oleh para ahli pragmatik. Pendekatan pragmatik digunakan untuk menjelaskan penggunaan tindak tutur penjual dan pembeli yang ditinjau dari segi modus dan fungsi tindak tutur ekspresif mereka berdasarkan konteks.

Sumber data penelitian ini, yaitu tuturan penjual dan pembeli di pasar tradisional Kota Baubau. Adapun, jenis datanya adalah data lisan berupa tuturan ekspresif yang digunakan penjual dan pembeli di pasar tradisional Kota Baubau.

Waktu pelaksanaan penelitian dilakukan selama satu bulan, mulai dari bulan Agustus 2017 sampai selesai. Penelitian ini berlokasi di pasar tradisional Kota Baubau. Pasar tradisional di Kota Baubau terdiri atas pasar Wameo, Laelangi, dan pasar Karya Nugraha. Tiga pasar tersebut dijadikan sebagai tempat penelitian.

Populasi dalam penelitian ini adalah keseluruhan modus dan tuturan ekspresif yang dituturkan oleh penjual dan pembeli di pasar tradisional Kota Baubau.

Pengambilan sampel pada penelitian ini digunakan teknik purposive sampling yaitu pemilihan sekelompok objek berdasarkan ciri-ciri populasi sesuai kebutuhan dalam membahas atau menganalisis permasalahan yang diteliti. Sampel diarahkan pada sumber data yang dipandang memiliki data penting yang berkaitan dengan permasalahan yang diteliti. Sampel pada penelitian ini mengacu pada jumlah populasi yang dapat mewakili tuturan ekspresif yang mengandung modus.

Metode yang digunakan adalah metode simak dengan mengumpulkan data langsung dari lapangan dengan cara merekam tindak tutur yang digunakan penjual dan pembeli dalam transaksi jualbeli yang berlangsung di pasar tradisional Kota Baubau.

Teknik yang digunakan dalam penelitian ini adalah teknik rekam dan catat.

1) Teknik Rekam

Perekaman data menggunakan alat perekam telepon seluler untuk merekam percakapan penjual dan pembeli di saat proses tawar-menawar berlangsung. Teknik rekam digunakan dengan pertimbangan bahwa data yang diteliti berupa tuturan lisan yang digunakan penjual dan pembeli di pasar tradisional Kota Baubau.

2) Teknik Catat

Dalam teknik catat yaitu penulis mencatat data-data yang ada hubungannya dengan masalah. Proses catat ini merupakan tindak lanjut dari teknik rekaman tindak tutur ekspresif yang digunakan penjual dan pembeli di pasar tradisional Kota Baubau.

Proses analisis data dimulai dengan menelaah seluruh data yang tersedia dari berbagai sumber, kemudian dijelaskan secara sistematis untuk memberikan gambaran secara cermat mengenai permasalahan yang dibahas sesuai dengan rumusan masalah dan tujuan penelitian.

Langkah-langkah

dalam menganalisis data dapat diuraikan sebagai berikut.

1. Pengidentifikasian data

Mengidentifikasi rekaman tuturan penjual dan pembeli yang telah dicatat, kemudian memilih bentuk tuturan yang mengandung modus dan fungsi tindak tutur ekspresif mereka.

2. Pengklasifikasian data

Melakukan klasifikasi pada data yang telah dikumpulkan, yakni tuturan yang mengandung modus dan fungsi tindak tutur ekspresif. Dalam penelitian ini, penarikan contoh berdasarkan identifikasi dari klasifikasi data yang diperoleh sehingga nomor urut data ditulis secara acak atau tidak tersusun.

3. Penganalisisan data 
Melakukan analisis pada data yang telah diidentifikasi dan diklasifikasi berdasarkan teori yang berkaitan dengan modus dan tindak tutur ekspresif.

mencapai analisis yang sesuai rumusan masalah, maka data yang di dari hasil rekaman tuturan penjual dan pembeli yang telah dicatat lalu dianalisis berdasarkan penomoran data.

\section{Penyimpulan}

Menyimpulkan hasil penelitian berdasarkan data yang telah dideskripsikan, diidentifikasi, diklasifikasi, dan dianalisis.

\section{PEMBAHASAN}

\section{Modus Tuturan Penjual dan Pembeli dalam Transaksi Jual-Beli di Pasar Tradisional Kota Baubau}

Tuturan penjual dan pembeli dianalisis berdasarkan pembagian modus. Pembagian modus tuturan penjual tersebut, yaitu: (1) modus deklaratif, (2) modus interogatif, dan (3) modus imperatif. Pada pembahasan ini akan dijelaskan penggunaan modus tuturan penjual dan dilanjutkan dengan menjelaskan penggunaan modus tuturan pembeli. Guna memperjelas pembahasan tersebut, berikut ini akan diawali dengan menjelaskan penggunaan tuturan penjual yang bermodus (1) deklaratif, (2) interogatif, dan (3) modus imperatif.

\section{a. Penjual}

\section{1) Modus Deklaratif}

Modus deklaratif digunakan untuk memberitakan sesuatu atau menginformasikan sesuatu. Guna memudahkan interaksi jual-beli antara penjual dengan pembeli, maka penjual dapat menginformasikan atau menyampaikan secara langsung kualitas barang yang dijual kepada pembeli. Dalam hal ini, penjual menggunakan modus deklaratif untuk memberitahukan sesuatu kepada pembeli hingga tanggapan yang diharapkan hanyalah berupa perhatian. Berkaitan dengan uraian tersebut, modus deklaratif dapat pula dipakai penjual untuk mengharapkan maksud yang dikehendakinya sendiri. Hal ini dapat diketahui apabila adanya kontribusi konteks yang melatarbelakangi tuturan penjual. Berikut beberapa contoh tuturan penjual yang bermodus deklaratif.

\section{Contoh (1)}

Konteks : Seorang pembeli sedang menawar harga baju kepada penjual pakaian.

Tempat : Pasar Laelangi Kota Baubau.

Peserta : Penjual dan pembeli.

\section{Percakapan:}

Pembeli : Berapa harga baju yang ini, Bu?

Penjual : Lima puluh ribu.

Pembeli : Dua puluh lima ribu mo.

Penjual : Modalnya saja tidak sampai. Belum lagi ongkos perjalanannya.

Pembeli : Oh ia makasih, Bu. (pergi).

Pada contoh (1), pembeli langsung menanyakan kepada penjual harga baju yang diminatinya. Tanpa basa-basi, penjual pun langsung menjawab sesuai harga pasnya. Pembeli menawar lima puluh persen dari harga yang disebutkan penjual. Mendengarkan hal tersebut, penjual menutup pintu tawar-menawar dengan menyebutkan hal yang paling mendasar dalam penjualan, yakni modalnya saja tidak sampai, belum lagi ongkos perjalanannya.

Berdasarkan penjelasan tersebut, terlihat penjual menggunakan modus deklaratif yang terdapat pada kalimat modalnya saja tidak sampai, belum lagi ongkos perjalanannya. Kalimat tersebut merupakan kalimat majemuk bertingkat yang terdiri atas kalimat utama modalnya saja tidak sampai dan anak kalimat belum lagi ongkos perjalanannya. Kalimat utama bermakna modal barang lebih besar dari nominal harga yang diajukan pembeli. Adapun anak kalimat merupakan penegasan terhadap kalimat utama tentang harga yang diajukan oleh pembeli tidak mencapai modal dasar barang tersebut. Dengan demikian, dapat dipahami bahwa penjual berupaya merasionalkan harga baju sehingga pembeli bisa memahami keadaan sebenarnya tentang 
modal baju dan keuntungan yang mesti diperoleh penjual.

Merujuk pada percakapan contoh (1), maka tampak bahwa interaksi jual-beli tidak mencapai kesepakatan harga. Dengan kata lain tidak berhasil. Hal ini ditandai pada kalimat oh ia makasih, Bu (pergi) yang dituturkan oleh pembeli. Ketidakberhasilan transaksi tersebut disebabkan oleh dua hal: pertama, baju bukan merupakan kebutuhan mendesak (sekunder); kedua, penjual baju di pasar tersebut banyak sehingga pembeli merasa masih bisa mendapatkan barang serupa di tempat lain sesuai harga yang diinginkan.

\section{2) Modus Interogatif}

Modus interogatif merupakan cara yang dipergunakan dalam mengajukan pertanyaan. Tentu dalam percakapan, perlu adanya pertanyaan diberikan kepada orang yang diajak bicara untuk memperoleh respon balik berupa informasi atau pun jawaban. Hal ini berlaku pula pada penjual di pasar tradisional Kota Baubau. Penjual memberikan pertanyaan pada setiap calon pembeli yang melintas di depan tokoh atau tempat dia menyiapkan barang yang dijual. Dalam hal ini penjual mengharapkan reaksi berupa jawaban dari pembeli atau bahkan pertanyaannya mengandung maksud yang dikehendakinya sendiri. Untuk lebih jelasnya, akan diutarakan pada contoh berikut.

\section{Contoh (2)}

Konteks : Seorang penjual menjual pisang raja.

Tempat : Pasar Wameo Kota Baubau.

Peserta : Penjual dan pembeli.

\section{Percakapan:}

Penjual : Pisang apa?

Penjual : Mau beli berapa sisir?

Pembeli : Berapa ini satu sisir?

Pembeli : Ini empat, ini dua.

Penjual : Yang empat lima puluh. Yang dua

sisir dua puluh ribu.

Pembeli : Berarti kena lima belas. Eh jangan. Sepuluh ribu mi.

Penjual : Mau dapat di mana sepuluh ribu. Kalau ada bawa di sini saya beli.

66

$$
\text { : Io. Itu mi. Berapa tadi }
$$

Penjual : Tujuh puluh saja. Terima kasih.

Pembeli : Ie. Terima kasih juga.

Dalam contoh (2) terlihat penjual menggunakan modus interogatif yang disampaikan kepada pembeli. Hal ini ditemukan pada kalimat pisang apa?. Penjual langsung bertanya walaupun sesungguhnya pembeli belum berbicara apapun tetapi pandangan matanya seakan mengatakan sesuatu sehingga penjual memberikan pertanyaan langsung. Merujuk pada konteks percakapan, modus interogatif digunakan penjual bertujuan menawarkan pisang kepada pembeli. Pertanyaan tersebut direspon oleh pembeli untuk mengetahui harga pisang yang dijual oleh penjual. Penjual pun menginformasikan harga tiaptiap pisang yang dibagi beberapa sisir atau tempat. Mendengarkan hal tersebut, pembeli menawar secara langsung harga pisang dengan cara menyebutkan nominal harga dan melarang penjual agar tidak mempertahankan harga pisangnya. Tawaran tersebut dianggap kurang pantas mengingat usia penjual lebih tinggi dibandingkan pembeli. Berkenaan dengan hal tersebut, penjual menutup tawaran pembeli dengan cara bertanya dan menyarankan kepada pembeli bahwa jika ada pisang yang murah, penjual pun akan membeli pisang tersebut. Dalam hal ini penjual mengimplisitkan maksudnya bahwa dirinya sedang marah karena menghadapi pembeli yang ngotot menawar harga pisang.

\section{3) Modus imperatif}

Modus imperatif digunakan untuk menyatakan perintah, ajakan, larangan, permohonan atau permintaan. Pada modus imperatif ini dapat direalisasikan dengan pertanyaan atau pun dalam bentuk deklaratif. Hal ini dapat terjadi apabila pemakaiannya disesuaikan dengan konteks yang melatarbelakangi setiap tuturan yang 
disampaikan penjual. Dalam hal ini, modus imperatif dipakai penjual hingga tanggapan yang diharapkan berupa tindakan dari pembeli. Guna memperjelas pembahasan tersebut, berikut beberapa contoh modus imperatif yang dituturkan penjual.

\section{Contoh (3)}

Konteks : Seorang penjual menjual terung.

Tempat : Pasar Wameo Kota Baubau

Peserta : Penjual dan pembeli

\section{Percakapan:}

Pembeli : Berapa ini? (menunjuk terung).

Penjual : Lima ribu. Masih muda itu.

Pembeli : Tidak kurang?

Penjual : Coba lihat tumpukannya ini eee, ada tujuh buah to.

Pembeli : (tidak membeli)

Melalui contoh (3) tampak seorang pembeli melihat dan menanyakan harga terung yang dijajakan penjual. Penjual langsung menginformasikan harga sekaligus memuji terung yang dijualnya bertujuan mempengaruhi pembeli agar membeli terung. Pembeli pun mendekatkan diri dengan cara memberikan pertanyaan bertujuan menawar harga terung yang ditetapkan penjual. Mendengarkan hal tersebut, penjual menghentikan tawaran pembeli dengan cara menyuruh pembeli untuk melihat kembali jumlah terung pada tiap-tiap tumpukan.

Berdasarkan uraian tersebut, terlihat penjual menggunakan modus imperatif yang disampaikan kepada pembeli. Hal ini ditemukan pada kalimat coba lihat tumpukannya ini eee, ada tujuh buah to. Modus imperatif pada kalimat tersebut ditandai oleh penggunaan frasa coba lihat yang bermakna menyuruh pembeli agar melihat sesuatu. Adapun kata tumpukannya merujuk pada terung. Secara keseluruhan kalimat tersebut bermakna penjual menyuruh pembeli agar melihat tumpukan terung yang berjumlah tujuh buah. Pada tuturan sebelumnya pembeli mengajukan permintaan agar harga tiap-tiap tumpukan terung dikurangi. Namun, permintaan tersebut ditolak oleh penjual dengan cara menyuruh pembeli untuk melihat tumpukan terung karena menurut versi penjual harga yang ditentukan sepadan dengan tiap-tiap tumpukan terung.

Proses tawar-menawar pada contoh (3) tidak mencapai kata sepakat. Artinya, bahwa penjual memilih untuk mempertahankan harga sedangkan pembeli meninggalkan tempat tersebut tanpa sepatah kata pun. Transaksi yang gagal seperti ini diakibatkan oleh beberapa hal: pertama, penjual ngotot mempertahankan harga dan menghindari penggunaan kalimat persuasif; kedua, pembeli tampaknya tidak senang dengan pelayanan penjual. Hal tersebut dapat dilihat pada sikap pembeli yang meninggalkan penjual tanpa sepatah kata pun.

\section{b. Pembeli}

\section{1) Modus deklaratif}

Modus deklaratif digunakan untuk memberitakan sesuatu atau meinformasikan sesuatu. Dalam proses tawar-menawar, tentu pembeli memiliki peran penting pula untuk mengekspresikan tuturannya. Hal ini dapat dilakukan secara langsung atau pun tidak langsung yang tergambar dalam tuturan yang mengandung modus deklaratif. Dengan demikian, pembeli pun mengharapkan agar maksud tuturannya dapat dimengerti oleh penjual. Guna memperjelas penggunaan tuturan pembeli, berikut beberapa contoh tuturannya yang bermodus deklaratif.

\section{Contoh (4)}

Konteks : Seorang pembeli menawar harga tahu.

Tempat : Pasar Wameo Kota Baubau.

Peserta : Penjual dan pembeli.

\section{Percakapan:}

Pembeli : Tahunya?

Penjual : Tiga lima ribu.

Pembeli : Sudah langganan juga.

Penjual : Masih murah itu kasian.

Tampak pada contoh (4) terlihat adanya perbedaan usia pembeli dan penjual. Usia penjual lebih tinggi dibandingkan usia pembeli. Hal tersebut terlihat pada kalimat 
yang digunakan pembeli, yakni tahunya. Adapun pronomina persona ketiga tunggal nya yang melekat pada kata tahunya merujuk pada penjual. Dalam hal ini digunakan pembeli sebagai bentuk penghargaan kepada penjual agar terlihat lebih sopan. Setelah mendengarkan pertanyaan pembeli, penjual langsung menginformasikan dan menentukan harga tahu. Mendengarkan hal tersebut, pembeli langsung menginformasikan dirinya sebagai pelanggan yang sering membeli tahu pada penjual. Penjual pun langsung menyampaikan bahwa tahunya sudah dijual dengan harga murah.

Berkenaan dengan uraian tersebut, terdapat modus deklaratif yang digunakan pembeli, yakni terdapat pada kalimat sudah langganan juga. Penggunaan modus deklaratif tidak hanya ditandai dengan penggunaan kalimat deklaratif melainkan lebih luas lagi seperti kandungan makna. Kandungan makna pada kalimat tersebut yaitu menginformasikan keadaan diri pembeli sebagai langganan. Pembeli menginformasikan dirinya sebagai pelanggan untuk mempengaruhi psikologis penjual. Asumsinya bahwa seorang pelanggan haruslah dilayani dengan baik, semisal memperoleh penurunan harga khusus dari penjual. Merujuk pada jawaban penjual masih murah itu kasian bertujuan meyakinkan pembeli bahwa dirinya telah memberikan harga murah. Pada konteks tersebut menunjukkan bahwa pembeli merupakan pelanggan yang dikenali. Penjual selalu mengutamakan dan menjaga hubungan baik dengan pelanggan dengan cara memberikan harga murah. Mendengarkan hal tersebut, pembeli terpengaruh dan membeli tahu sesuai harga yang ditetapkan penjual. Jadi dapat dipahami bahwa modus deklaratif yang digunakan pembeli bertujuan untuk menawar harga tahu.

\section{2) Modus Interogatif}

Modus interogatif merupakan cara yang dipergunakan dalam mengajukan pertanyaan. Pertanyaan yang diberikan akan mendapatkan jawaban dari orang diajak bicara. Dalam percakapan sehari-hari, misalnya pertanyaan yang diberikan oleh orang tua kepada anaknya, yakni jam berapa berangkat ke sekolah?. Tentu, pertanyaan ini diberikan dengan harapan mendapatkan informasi atau pun jawaban dari sang anak. Jadi sang anak akan memberikan alternatif jawaban seperti jam enam, $B u$ atau pun jawaban lain yang berkaitan langsung dengan pertanyaan.

Berkaitan dengan uraian di atas, pembeli pun akan memberikan pertanyaan kepada penjual. Pertanyaan pembeli akan disampaikan dengan harapan mendapatkan jawaban dari penjual atau pun digunakan hingga maksud tuturannya dikehendaki oleh dirinya. Hal ini dapat terjadi apabila disesuaikan dengan konteks yang melatarbelakangi pertanyaannya. Untuk lebih jelasnya akan diuraikan pada beberapa contoh yang mewakili, yakni seperti berikut ini.

\section{Contoh (5)}

Konteks : Seorang pembeli menawar harga gula merah.

Tempat : Pasar Laelangi Kota Baubau.

Peserta : Penjual dan pembeli.

\section{Percakapan:}

Pembeli : Berapa gula yang ini?

Penjual : Enam ribu.

Pembeli : Kasih tiga lima belas ribu saja.

Penjual : Tidak bisa kasian.

Pembeli : Sudah pecah ini gulanya.

Penjual : Sudah murah mi itu saya kasih enam ribu.

Melalui contoh (5) terlihat pembeli menggunakan modus interogatif yang disampaikan kepada penjual. Hal ini ditemukan pada kalimat berapa gula yang ini?. Penggunaan kata berapa merupakan penanda modus interogatif yang bermakna menanyakan jumlah. Secara umum kalimat berapa gula yang ini? bermakna menanyakan harga gula. Penjual pun menginformasikan harga. Mendengarkan hal tersebut, pembeli langsung menawar dengan cara menyebutkan nominal harga yang 
diinginkan tetapi penjual tidak menyetujui permintaan tersebut. Merujuk pada konteks percakapan, pembeli menggunakan modus interogatif bertujuan menanyakan harga gula.

\section{3) Modus Imperatif}

Modus imperatif merupakan modus kalimat yang dibentuk untuk memancing respon berupa tindakan. Dalam hal ini dapat diwujudkan dalam bentuk perintah, ajakan, larangan, permohonan atau pun permintaan. Pada modus imperatif ini dapat direalisasikan dengan pertanyaan atau pun dalam bentuk deklaratif. Hal ini dapat terjadi apabila disesuaikan dengan konteks yang melatarbelakangi setiap tuturan yang disampaikan pembeli. Penggunaan modus imperatif ini dapat dilakukan secara langsung atau pun tidak langsung agar menyenangkan orang yang diajak bicara. Guna memperjelas pembahasan ini, berikut beberapa contoh tuturan pembeli yang bermodus imperatif.

\section{Contoh (6)}

Konteks : Seorang penjual menjual gula

Tempat : Pasar Wameo Kota Baubau.

Peserta : Penjual dan pembeli.

\section{Percakapan:}

Penjual : Gula. Ini delapan puluh. Kalau yang ini seratus. Ini seratus sepuluh.

Pembeli : Satu ikat ini to. Berapa kalau ini?

Penjual : Seratus sepuluh.

Pembeli : Ih jangan begitu!. Kalau lima biji?

Penjual : Lima puluh lima. Bagus itu biar tidak dirobek.

Pembeli : Mau pastikan saja. Merah atau agak hitam.

Dari contoh (6), penjual menjual gula merah perikatnya sebanyak sepuluh buah.
Tiap satu ikat dijual dengan harga delapan sampai seratus sepuluh ribu. Penjual menawarkan barangnya dengan cara menginformasikan langsung tiap-tiap harga gula kepada pembeli. Pembeli bertanya untuk mengetahui harga gula. Penjual pun menginformasikan harga gula. Mendengarkan hal tersebut, pembeli langsung menawar harga gula.

Berkenaan dengan penjelasan tersebut dan merujuk pada konteks, terlihat penjual menggunakan modus imperatif, yakni ih jangan begitu!. Hal ini ditandai kata jangan yang bermakna melarang agar tidak melakukan sesuatu. Adapun modus imperatif digunakan pembeli bertujuan menolak ketentuan harga dari penjual. Pembeli memberikan penolakan karena dia berusaha merasionalkan jumlah gula satu ikat sebanyak sepuluh buah semestinya dijual sepuluh ribu per bijinya. Tampaknya cara tersebut tidak disetujui oleh penjual. Penjual menghentikan keinginan pembeli dengan cara mempertahankan harga dan memuji kualitas gula yang dijual oleh dirinya. Mendengar hal tersebut, pembeli pun pergi tanpa membeli gula.

Berdasarkan uraian di atas, modus deklaratif dituturkan penjual yang bermaksud melarang dan menolak, modus interogatif digunakan penjual yang bermaksud menawarkan dan mempersilakan, dan modus imperatif yang dituturkan penjual yang bermaksud menolak, menyuruh, dan membujuk. Selanjutnya, ditemukan modus deklaratif yang dituturkan pembeli yang bermaksud menawar, modus interogatif dituturkan pembeli yang bermaksud bertanya dan menawar, dan modus imperatif yang dituturkan pembeli yang bermaksud menolak, menawar, dan menyuruh. Untuk lebih jelasnya, penggunaan modus penjual dan pembeli berdasarkan konteksnya dapat dilihat pada tabel berikut.

Tabel 1.

Rekapitulasi modus tuturan penjual dan pembeli.

\begin{tabular}{|l|l|l|l|}
\hline & $\begin{array}{c}\text { Jenis } \\
\text { Modus }\end{array}$ & Contoh Tuturan & \multicolumn{1}{c|}{ Maksud } \\
\hline & & a. Modalnya saja tidak sampai. Belum lagi ongkos & a. Menolak. \\
\hline
\end{tabular}




\begin{tabular}{|c|c|c|c|}
\hline \multirow[t]{3}{*}{ Penjual } & Deklaratif & $\begin{array}{l}\text { perjalanannya. } \\
\text { b. Ubi sekarang susah ditanam. } \\
\text { c. Harganya saja satu karung seratus delapan } \\
\text { puluh. } \\
\text { d. Ikan enak ini eee. }\end{array}$ & $\begin{array}{l}\text { b. Menolak. } \\
\text { c. Menolak } \\
\text { d. Menolak. }\end{array}$ \\
\hline & Interogatif & $\begin{array}{l}\text { a. Pisang apa? } \\
\text { b. Yang mana Bu? } \\
\text { c. Apa itu? }\end{array}$ & $\begin{array}{l}\text { a. Menawarkan. } \\
\text { b. Menawarkan. } \\
\text { c. Mempersilahkan. }\end{array}$ \\
\hline & Imperatif & $\begin{array}{l}\text { a. Coba lihat tumpukannya ini eee!. Ada tujuh } \\
\text { buah to. } \\
\text { b. Coba mi dulu! } \\
\text { c. Mending ambil yang begini! }\end{array}$ & $\begin{array}{l}\text { a. Menolak. } \\
\text { b. Membujuk. } \\
\text { c. Membujuk. }\end{array}$ \\
\hline \multirow{3}{*}{ Pembeli } & Deklaratif & $\begin{array}{l}\text { a. Sudah langganan juga. } \\
\text { b. Jumlah tangkainya saja bisa dihitung. } \\
\text { c. Masalahnya kita mau jual juga ini. }\end{array}$ & $\begin{array}{l}\text { a. Menawar. } \\
\text { b. Menawar. } \\
\text { c. Menawar. }\end{array}$ \\
\hline & Interogatif & $\begin{array}{l}\text { a. Berapa gula yang ini?, } \\
\text { b. Bukannya harga cabe lagi turun? } \\
\text { c. Tidak kurang? }\end{array}$ & $\begin{array}{l}\text { a. Bertanya. } \\
\text { b. Menawar. } \\
\text { c. Menawar. }\end{array}$ \\
\hline & Imperatif & $\begin{array}{l}\text { a. Ih jangan begitu!... } \\
\text { b. Kasih kurang mi Bu! } \\
\text { c. Coba ambilkan yang itu saja! }\end{array}$ & $\begin{array}{l}\text { a. Menolak. } \\
\text { b. Menawar. } \\
\text { c. Menyuruh. }\end{array}$ \\
\hline
\end{tabular}

\section{PENUTUP}

Berdasarkan uraian pada pembahasan maka penulis dapat menarik beberapa simpulan yang selaras dengan tujuan penelitian, yaitu terdapat tiga modus tuturan yang digunakan penjual dan pembeli, yakni modus deklaratif, modus interogatif, dan modus imperatif. Penggunaan modus tuturan penjual dan pembeli dipengaruhi oleh beberapa konteks sehingga maksud yang dikehendaki oleh mereka pun berbeda. Modus interogatif penjual digunakan untuk menanyakan sekaligus mempersilakan pembeli untuk mencari dan memilih barang yang dibutuhkannya. Modus deklaratif penjual digunakan untuk mempertahankan harga (menolak) tawaran pembeli dengan cara menyebutkan sumber dan harga barang sedangkan modus imperatif penjual digunakan untuk membujuk pembeli agar mencoba tiap-tiap barang yang ditawarkan oleh penjual. Selanjutnya, ditemukan tiga modus yang digunakan pembeli, yaitu modus deklaratif, modus interogatif, dan modus imperatif. Modus deklaratif digunakan pembeli sebagai upaya menawar harga barang dengan cara menyampaikan bahwa dirinya merupakan langganan yang

sering membeli barang yang dijajakan penjual. Modus interogatif digunakan pembeli untuk bertanya sekaligus bertujuan menawar harga. Modus imperatif digunakan pembeli yang bertujuan meminta penjual agar mengurangi harga barang sesuai permintaan pembeli.

\section{DAFTAR PUSTAKA}

Chaer, Abdul dan Leonie Agustina. 2004. Sosiolinguistik: Perkenalan Awal. Jakarta: Rineka Cipta.

Djajasudarma, T. Fatimah. 1993. Metode Linguistik: Ancangan Metode Penelitian dan Kajian. Bandung: PT Eresco.

Effendy, Onong Uchjana. 2004. Dinamika Komunikasi. Bandung: PT Remadja Rosdakarya.

Gunawan, Fahmi. 2013. "Wujud Kesantunan Berbahasa Mahasiswa terhadap Dosen di Stain Kendari: Kajian Sosiopragmatik". Jurnal Arbitrer Vol. 1, No. 1, Oktober, Hal: 8-18.

Gusnawaty. 2011. "Perilaku Kesantunan dalam Bahasa Bugis:Analisis 
Sosiopragmatik". Disertasi. Makassar. Pascasarjana Universitas Hasanuddin. Ibrahim, Abdul Syukur. 1993. Kajian Tindak Tutur. Surabaya: Usaha Nasional.

Kridalaksana, Harimurti. 1993. Kamus Linguistik. Jakarta: PT. Ikrar Mandiri Abadi.

Leech, Geoffrey. $1983 . \quad$ Principles of Pragmatics. New York: Longman.

Pranowo. 2009. Berbahasa secara Santun. Yogyakarta: Pustaka Pelajar.

Rahardi, Kunjana. 2008. Pragmatik: Kesantunan Imperatif Bahasa Indonesia. Jakarta: Erlangga.

Rohmadi, Muhammad. 2004. Pragmatik: Teori dan Analisis. Yogyakarta: Lingkar Media.

Rustono. 1999. Pokok-Pokok Pragmatik. Semarang: CV. IKIP Semarang Press.

Sandilatta, Ekky Cintyaresi. 2008. "Analisis Tindak Tutur Pada Film "Garuda di Dadaku" Karya Ifa Ifansyah". Jurnal Artikulasi Vol. 7, No. 1, Februari, Hal: 1-15.

Soeparno. 2002. Dasar-Dasar Linguistik Umum. Yogyakarta: Tiara Wacana.
Tarigan, Henry Guntur. 1990. Teknik Pengajaran Keterampilan Berbahasa. Bandung: Angkasa

Taufik. 2017. "Deiksis Persona Bahasa Indonesia Dialek Ambon". Junal Totobuang. Vol. 5, No. 2. Ambon: Kantor Bahasa Maluku

Taufik. 2018. "Relasi Kekerabatan Bahasa Hitu, Wakal, Morela, Mamala, dan Hila di Provinsi Maluku". Junal Totobuang. Vol. 6, No. 1. Ambon: Kantor Bahasa Maluku

Thomas, Jenny. 1995. Meaning in Interaction: An Introduction to Pragmatics. London/New York: Longman.

Wijana, Dewa Putu. 1996. Dasar-Dasar Pragmatik. Yogyakarta: Andi Offset.

Yule, George. 2006. Pragmatik. Terjemahan Indah Fajar Wahyuni. Yogyakarta: Pustaka Pelajar.

Zamzani. 2007. Kajian Sosiopragmatik. Yogyakarta: Cipta Pustaka. 